The results obtained are as follows:

1) The dehydrofluorination in the absence of catalyst at temperatures higher than $750^{\circ} \mathrm{C}$ is of the first order kinetics and the reaction rate constant $k$ is given by

$$
k=1.63 \times 10^{10} \exp (-53800 / R T)
$$

2) As in the dehydrofluorination of $\mathrm{CH}_{8} \mathrm{CHF}_{2}$ which was reported by us previously, (synthesized) $\mathrm{AlF}_{3}, \mathrm{FeF}_{3}, \mathrm{MgF}_{2}$ are acive for dehydrifluorination at lower temperature as $530^{\circ} \mathrm{C}$, while (commercial) $\mathrm{AlF}_{3}, \mathrm{CaF}_{2}, \mathrm{SrF}_{2}, \mathrm{BaF}_{2}, \mathrm{ZnF}_{2}, \mathrm{CdF}_{2}, \mathrm{MnF}_{2}, \mathrm{SnF}_{2}$ are inactive. All the catalytically active fluorides have some acidity, while inactive fluorides have none, and hence the acidity appears to be oirrelated with the catalytical activity.

3) Basic aluminum fluoride has been found active and the most stable. The dehydrofluorination reaction catalyzed by this catalyst has been proved to be surface reaction controlling, and the activation energy is $28.3 \mathrm{kcal} / \mathrm{mol}$.

\title{
パラジゥム $(\mathbf{I I})-$ 銅 $(\mathbf{I I})$ ゼオライト $\mathbf{Y}$ 触媒による プロピレンの酸化反応
}

\author{
（1972 年 4 月 10 日 受 理）
}

\section{久保俊厗・熊田文雄・富永博夫・功刀泰碩*}

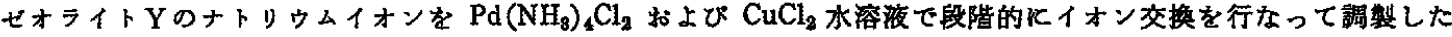
$\mathrm{Pd}$ (II) $-\mathrm{Cu}$ (II) $-\mathrm{Y}$ ゼオライト触媒を使用して，水蒸気存在下でのプロビレンの酸化反応を行なった。100 150 $\mathrm{C}$

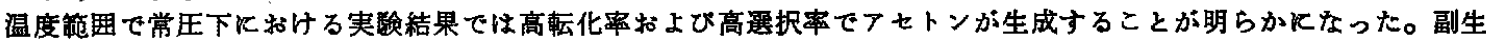

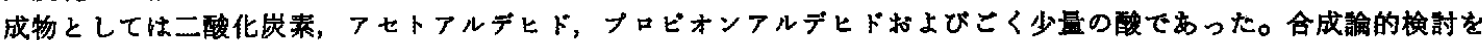

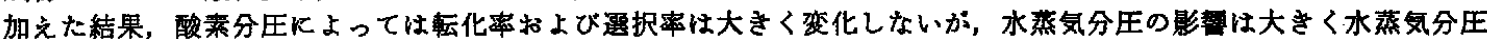
が大になるにしたがって転化率は上年し，アセトンの選択率は減少の傾向を示す。反応温度が $140^{\circ} \mathrm{C}$ 采では温度の 上年とともKてセトン生成の活性は上年するが, $140^{\circ} \mathrm{C}$ 以上ではブロビレンの配位が困難になり活性が低下するとと るとアセトンの選択率る $80 \%$ まで低下する。この触媒系ではゼオライト構造内の定められた位置に存在する反応に よって還元された $\mathrm{Pd}(0)$ と $\mathrm{Cu}($ III) の間の電子移行が行なわれている。供給する水少量のアンモニてを添加する と活性は徐々飞低下し, 反応後の触媒は銅 (II)アンミン錯イオンの色调を示していること, 拉よび $\mathrm{Pd}\left(\mathrm{NH}_{3}\right)_{4}(\mathrm{II})-\mathrm{Cu}$ ・ $\left(\mathrm{NH}_{3}\right)_{8}(\mathrm{II})-\mathrm{Y}$ 触媒では低い活性しか示さないことから，Pd（II）-Cu（II）-Y 触媒系での螌媒活性種は部分的にアコ化 された $\mathrm{Pd}(\mathrm{II})$ イオンであろうと考えられる。
\end{abstract}

\section{1 腥}

ゼオライトの Naイオンは遷移金属イオンによってイオン交換 することがでさる。ゼオライト上に配置されたこの遷移金属イオ ンは溶夜中で示すのと類似の触媒作用を示す可能性が考えられ る。しかし，ある種の㜯移金属イオンはゼオライト上で還元され やすいので，還元され難い金属イオシを選ぶか，または還元され

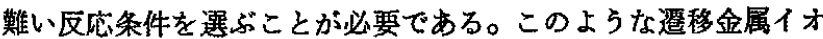
ンの安定性を考魔して，遷移金属イオン交换ゼオライト触媒を酸 化反応に使用している例が多い。たとえば，Van Sickle らうの $\mathrm{Co}$ (II) $-\mathrm{X}$ による ブテンの酸化, Mochida $5^{2) \sim 4)}$ の $\mathrm{Cu}($ II $)-\mathrm{Y}$

* 東京大学工学部合成化学科, 東京都文京区本很

1) D. E. Van Sickle, M. L. Prest, J. Catal., 19, 209(1970).

2) I. Mochida, S. Hayata, A. Kato, T. Seiyama, ibid., 15, 314(1969).

3) I. Mochida, S. Hayata, A. Kato, T. Seiyama, ibid., 19, $405(1970)$.
によるブロピレンの酸化， Rouchaud 55)の $\mathrm{Cu}(\mathrm{II}), \mathrm{Mn}$ (II)， $\mathrm{Ni}$ (II)，Co(II)-X による n-へキサンの酸化，また含浸法によ って調製した Mo-X 飞よるプロピレンの酸化6) などが報告され ている。その他，邆移金属イオン交換ゼオライト触媒によるシク

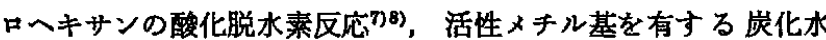
素のアンモ酸化によるニトリルの合成(10) などの論文がある。

4) I. Mochida, S. Hayata, A. Kato, T. Seiyama, J. Catal., 23, 31(1971).

5) J. Rouchaud, L. Sondengam, J. J. Fripiat, Bull. Soc. Chim. Fr., 1968, 4387.

6) J. Rouchaud, J. J. Fripiat, ibid., 1969, 78.

7) I. Mochida, T. Jitsumatsu, A. Kato, T. Seiyama, Bull. Chem. Soc. Jap., 44, 2595(1971).

8）久保俊彦，冨永博夫，功刀泰碩，日化，1972， 196.

9) L. V. Skalkina, I. K. Kolchin, L. Ya. Margolis, N. F. Ermolenko, S. A. Levina, L. M. Malashevich, Kinet. Katal., 12, 242(1971).

10) U. S. P., 3, 412, 134(1969). 
著者らは，゙゙オライト Yの NaイオンをPd(II) および Cu(II) イオンKよって交奥した Pd(II)-Cu(II)-Y ゼオライト触蝶を用

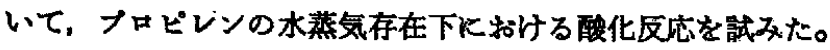

バラジウム塩を触媒とするオレフィンの 酸化反応が Smidt"11) とよって見いだされて以来，この反応を気固相系で接触的に行な

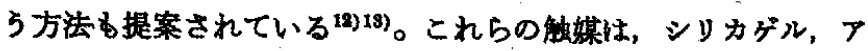
ルミナ、ケイソウ土などKパラジウム塩および $\mathrm{Pd}(0) \rightleftarrows \mathrm{Pd}($ II $)$ 上りも酸化邆元電位が上位でかつ酸素分子によって容易火高原子 価状態にもとり得る塩化銅（II）なとの金属塩の両者を担持したす のまたなパラジウム塩を活性庆に担持し，その再酸化作用を利 用したすのである。さらに酸化パラジウムる同様にオレフィンか らケトンあるいはフルデヒドの合成用触媒として有效であること が報告されている16)。

著者らはゼオライトYの $\mathrm{Na}$ イオンを $\mathrm{Pd}\left(\mathrm{NH}_{8}\right)_{4} \mathrm{Cl}_{2}$ 水溶液に よってイオン交換した $\mathrm{Pd}(\mathrm{II})-\mathrm{Y}$ ゼオンイトが，酸素蛙よび水 の存在下でオンフィンを酸化してヶトンまたはアルデヒドを合成 する触媒となり得ることを見いだした。さらに Pd(II) イオンで 交換されず残った Naイオンを $\mathrm{Cu}(\mathrm{II})$ イオンで交換すること に上り $\operatorname{Pd}(0) \longrightarrow \operatorname{Pd}(I I)$ なる再酸化が促進され，触媒活性がい らじるしく上昇し，かつ寿命が改善されることを見いだした。

\section{2 実験}

\section{1 蝶の調整}

实験には Linde 社製モレキュラーシーブ Y（SK-40）を使用 した。その組成性， $\mathrm{SiO}_{2} 63.5 \% ， \mathrm{Al}_{2} \mathrm{O}_{3} 23.5 \% ， \mathrm{Na}_{2} \mathrm{O} 13.0 \%$ ，

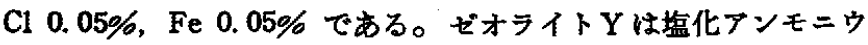
ムの飽和水溶液を入れたデシターター中で水を平衡吸着させたの ち种量した。ゼオライトYの NaイオンをPd(II) および Cu(II) イオンにより二段階でイオン交換を行なった。第一段階は Pd・ $\left(\mathrm{NH}_{8}\right)_{4} \mathrm{Cl}_{2}$ 水溶液を第二段階怯 $\mathrm{CuCl}_{2}$ 水溶液をそれぞれ 使用し た。第一段階，すなわち $\mathrm{Pd}\left(\mathrm{NH}_{8}\right)_{4} \mathrm{Cl}_{2}$ 水溶液を用いるイオン交 換の場合飞は，Pd(II) イオンの均一な分散を実現するためにゼ

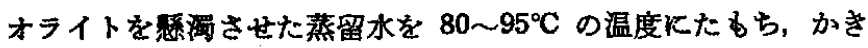
まぜながらこの中へ $0.2 \mathrm{~N}$ の $\mathrm{Pd}\left(\mathrm{NH}_{3}\right)_{4} \mathrm{Cl}_{2}$ 水溶液を約 1 時間か けて滴下し，滴下終了後す加熱・かきまぜを 3 時間つつけけたのち 1 日放置した。きた第二段階の $\mathrm{CuCl}_{2}$ 水溶液によるイオン交換 では, 70 $90^{\circ} \mathrm{C}$ で量論量の 3 倍の $\mathrm{CuCl}_{2}$ 皮溶液を約 1 時間かけ て滴下し，2時間かきまぜつづけたのち1日放置しだ。イオン交 換のたびことに，口過して Cl- が検出されなくなるまで洗浄し た。その後 $110^{\circ} \mathrm{C} て ゙ 1$ 日乾燥したのち， $300 \mathrm{~kg} / \mathrm{cm}^{2}$ で王縮成型 を行ない，碎いて 10〜20 メッシュの大きさ整えた。Pd(II) および $\mathrm{Cu}($ II) イオンの担持量は，各段階の液中の $\mathrm{Pd}(\mathrm{II})$ 打 よび $\mathrm{Cu}(\mathrm{II})$ イオンの残存量を EDTA 溶液によって滴定し定量 した。本実験で使用した $\mathrm{Pd}(\mathrm{II})-\mathrm{Cu}(\mathrm{II})-\mathrm{Y}$ 触媒の $\mathrm{Pd}(\mathrm{II})$ 扰よ び $\mathrm{Cu}$ (II) イオンの担持量はそれぞれ $1.0 \mathrm{wt} \%$ および $6.5 \mathrm{wt} \%$ であった。

11) J. Smidt, Angew. Chem., 71, 176(1959) ; 74, 93(1962).

12) U.S.P., 3, 131, 223(1964).

13）藤元 蒸, 根上泰彦, 功刀泰碩, 工化， $73 ， 1822(1970)$.

14) 藤元 薏, 竹田 博, 荒井弘通, 水尾样一, 功刀泰碩, 工 化, $73,2168(1970)$.

15）日特公, 昭 42-26001.

16）日特公，昭 43-29730.

\section{2 反応装证と実験方法}

反応装置は通常の固定床流通式反応装置を使用した。内径 17 $\mathrm{mm}$ のパイレックス製反応管に $2 \mathrm{~g}$ の触媒を充テンし, 原料のフ ロピレン，酸素怙よび窒莱（分圧を調整するため）を反応管上部 から供給する。また本をマイクロフィーダーで供給した。反仙 常圧で行なった。反応後のガス状酸化生成物は 4 6 $6^{\circ} \mathrm{C}$ 飞冾却し た水にくぐらせて吸收させ，その水溶液をガスクロマトグラフ、 一で分析し定量した。アルデとドおよびヶトンの分析にはポリエ チレングリコール $\left(3 \mathrm{~m}, 80^{\circ} \mathrm{C}\right)$ を，酸分析火はジブロピレンセ バケートカラム $\left(2 \mathrm{~m}, 110^{\circ} \mathrm{C}\right)$ を使用した。二酸化炭素の分析化 はシリカゲルカラム $\left(2 \mathrm{~m}, 80^{\circ} \mathrm{C}\right)$ を使用した。

\section{3 結果および考察}

\section{$3.1 \mathrm{Pd}(\mathrm{II})-\mathrm{NaY}$ によるブロビレンの酸化}

最初飞, $\mathrm{Cu}$ (II) を担持していない $\mathrm{Pd}$ (II) $-\mathrm{NaY}$ 触媒を使用 してブロピレンの酸化反応を行なった結果を图 1 亿示す。実験 (1)（2）のいずれの揚合す反応時間の経過ととすにアセトンの 生成速度が減少する。二つの実験とる触媒に担持された $\mathrm{Pd}(I)$ イオンに対して量論量以上（それでれ約 4.5 倍怙よび約 1.6 倍） のアセトンが生成していることから，触媒反応であることは明ら かである。二つの実験を比較してみると，酸素分殴が大である実 験（1）の昜合にはアセトン生成が多く活性性徐くに減少するが, フクロレインはごく徽嘼しか生成しない。一方，実輸（2）の酸 妻分圧が小のをきにはアセトンの生成速度の減少ととるにアク口 レインが增加する。パシジウム金属がアクロレインの生成反応に 触媒として働くことが知られているので1718)，Pd(II）が缱元さ れて徐々飞 $\mathrm{Pd}(0)$ 变化していることが推測される。

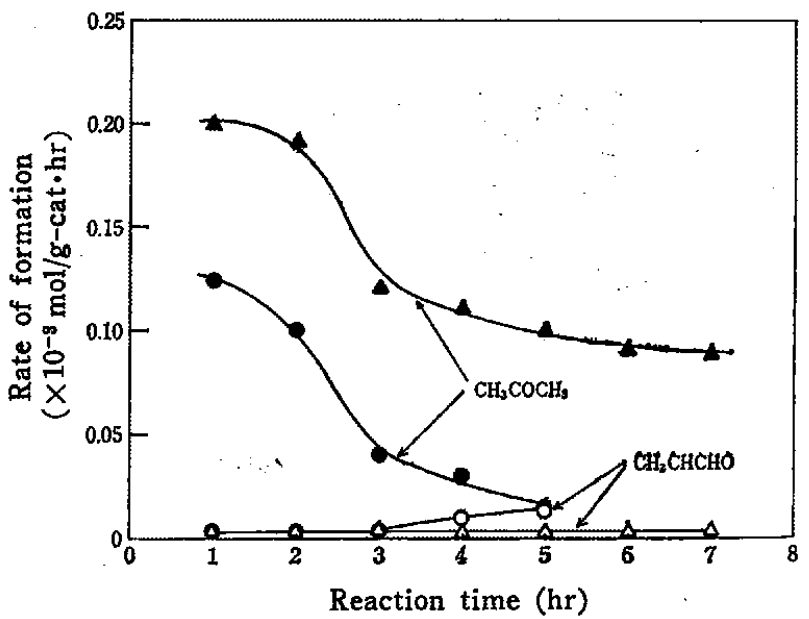

Fig. 1 Oxidation of propylene over $\mathrm{Pd}$ (II)-NaY catalyst Exp. $1 \triangle \Delta$, : Temperature $130^{\circ} \mathrm{C}$, Propylene partial pressure $0.033 \mathrm{~atm}$, Oxygen partial pressure $0.163 \mathrm{~atm}$, Water partial pressure $0.174 \mathrm{~atm}, W / F 3.3 \mathrm{~g}$-cat. $\mathrm{hr} / \mathrm{mol}$

Exp. $2 O, O$ : Temperature $140^{\circ} \mathrm{C}$, Propylene partial pressure $0.11 \mathrm{~atm}$, Oxygen partial pressure $0.10 \mathrm{~atm}$, Water partial pressure $0.79 \mathrm{~atm}, W / F 6.2 \mathrm{~g}-\mathrm{cat} \cdot \mathrm{hr} / \mathrm{mol}$

17）清山哲郎，荒牧 稳，竹山尚堅，山添 昇，工化，74，672 (1971).

18）藤元 蒸, 吉野浩樹, 功刀泰碩, 日化, 1972，507. 
実触（1），(2）の反応初期にアセトンが生成するのは主として Pd(II) イオンによる量論反応と考えられるが，量猃量以上のア セトンの生成化いてはつぎの二つの考え方があろら。

第 1 の考方方は，アセトン生成によって還元された $\operatorname{Pd}(0)$ が 気相中の酸素と反応し PdO を形成し，酸化パラジウムが触媒とし て酸くとするるのである。著者らの研究 ${ }^{19)}$ にれれは， $\mathrm{Pd}\left(\mathrm{NH}_{8}\right)_{\mathbf{4}^{*}}$ $\mathrm{Cl}_{2}$ 水溶液でイオン交换啳, $110^{\circ} \mathrm{C}$ で乾嬠し $500^{\circ} \mathrm{C} て 3$ 時間本素 還元した触媒では，バラジウム金属は高度に分散しており，脱水 䒺活性などの金属としての性質に乏しく，ブロピレンの水蒸気存 在下に拉る酸化反応においてもアクロレインよりもアセトンの 生成選択率が高いといら結果が得られている。この場合，パラジ ウム金属の徽小粒子が酸化パラジウムの形で颠いていることが示 咬されている。

第 2 の考え方は, アセトン生成によって還元された $\operatorname{Pd}(0)$ が 気相中の酸素によって Pd(II) イオンにもとるとするすのであ る。Riekert ${ }^{20)}$ によれば Ni(II)-ゼオライトに関して可逆的な還 元・酸化が起こり得ることが示されている。一般にm船の金属イ オンに関して記述すればつぎのとおりである。

$\left[\mathrm{Me}^{m+} m \mathrm{Z}^{-}\right]+m / 2\left(\mathrm{H}_{2}\right) \mathrm{g} \rightleftarrows\left[m\left(\mathrm{H}^{+} \mathrm{Z}^{-}\right), \mathrm{Me}^{0}\right]$

ただし Z゙ はゼオライトのアニオン点とする。

また $\mathrm{Cu}(I I) ， \operatorname{Ag}(\mathrm{I})$ なとでは気相中の酸素《よって容易に再 酸化されることが明らか火された。すなわち、

$$
\begin{aligned}
& 2\left[\mathrm{H}^{+} \mathrm{Z}^{-}, \mathrm{Cu}^{+}\right] \stackrel{1 / 2 \mathrm{O}_{2}}{\longrightarrow} 2\left[\mathrm{Cu}^{2+} 2 \mathrm{Z}^{-}\right]+\mathrm{H}_{2} \mathrm{O} \\
& 2\left[\mathrm{H}^{+} \mathrm{Z}^{-}, \mathrm{Ag}^{0}\right] \stackrel{1 / 2 \mathrm{O}_{2}}{\longrightarrow} 2\left[\mathrm{Ag}^{+} \mathrm{Z}^{-}\right]+\mathrm{H}_{2} \mathrm{O}
\end{aligned}
$$

酸素分圧が大である実倹（1）の場合は，Pd（II）がアセトン生成 によって還元されてる比較的すみやかにつぎの式によって再酸化 されるため，速度こそ減少するがアセトン生成がつつくとするす のである。

$$
\left[\mathrm{Pd}^{0}, 2 \mathrm{H}^{+} \mathrm{Z}^{-}\right] \stackrel{1 / 2 \mathrm{O}_{2}}{\longrightarrow}\left[\mathrm{Pd}^{2+} 2 \mathrm{Z}^{-}\right]+\mathrm{H}_{2} \mathrm{O}
$$

触媒種としては以上の二つの考方方があるが，Pd(II)-NaYの 場合どちらが正しいかは明らかではない。

\section{$3.2 \operatorname{Pd}(\mathrm{II})-\mathrm{Cu}(\mathrm{II})-\mathbf{Y}$ によるブロピレンの酸化}

$\mathrm{Pd}(\mathrm{II})-\mathrm{Na}-\mathrm{Y}$ 触媒では $\mathrm{Pd}(\mathrm{II})$ の選元速度が $\mathrm{Pd}(0)$ の再酸化 速度を上まわるため，触媒上の $\mathrm{Pd}(\mathrm{II})$ 訾度は次第に減少する。 触媒調製時に $\mathrm{Pd}($ II) でイオン交換されずに残存する $\mathrm{Na}$ イオン をさらに $\mathrm{Cu}(\mathrm{II})$ でイオン交換することによって $\mathrm{Pd}(0)$ の再酸 化を加速することが可能であろらと考えた。このような意図のる とで調製した $\mathrm{Pd}(\mathrm{II})-\mathrm{Cu}(\mathrm{II})-\mathrm{Y}$ 触媒は予想したと括り触媒活珄 が $\mathrm{Cu}$ (II) を担持していない触媒 Pd(II) - Na-Y K比較していち じるしく上昇し，かつ活性低下の現象が認められなかった（図 2 参照)。 1 wt $\% \mathrm{Pd}$ (II) $-\mathrm{NaY}$ と 7.2 wt $\% \mathrm{Cu}$ (II) - $\mathrm{Y}$ の粉末 ${ }^{21)}$ 重量比で 1:1 の割合で機械的に混合し，成型した触媒について の実鈳結果もすわせて図 2 に示す。 $\mathrm{Cu}$ (II)-Yではこの条件下て アセトンの生成ははとんど見られない。また Pd(I)-NaY の活 性はきわめて低い。そ机にもかかわらず，これらを機械的混合

19）久保俊彦，荒井弘通，冨永博夫，功刀泰碩，日化，投稿予 定.

20) L. Riekert, Ber. Bunsenges Phys. Chem., 73, 331(1969).

21) 粒度は約 $5 \mu$.

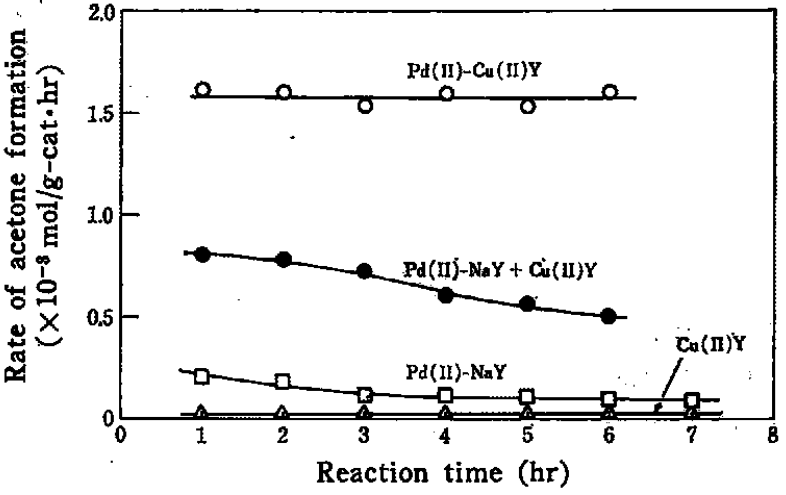

Fig. 2 Activity increase by $\mathrm{Cu}$ (II) addition Temperature $130^{\circ} \mathrm{C}$, Propylene partial pressure $0.031 \mathrm{~atm}$, Oxygen partial pressure $0.125 \mathrm{~atm}$, Water partial pressure $0.252 \mathrm{~atm}, W / F 9 \mathrm{~g}$-cat.hr/mol

した（Pd(II)-NaY+Cu(II)-Y) 触媒の活性梳かな大きい。た たし，おそらくは Cu(I) 濃度が不足のためと思われるが，徐々 に活性が低下する。機峨的に泥合した触媒で Pd(0) が再酸化さ れるのは興味樑い。

以上のよラにイオン交換によって調製した $\mathrm{Pd}$ (II)-Cu(II)-Y ゼオライト触某が，我蒸気存在下でのプロピレンの酸化反応に有 効な触媒であることが明らがなったので，反応諸因子の影響を 検討した。

この触媒反応においては主生成物はアせトンであり，副生成物 としては二酸化炭来，アせトアルデヒド,プロピオンフルデヒド， それにごく微量の酸が存在する。従来の塩化パラジウムー塩化銅 （II）系触媒反応化みられるような塩素化合物の生成は起こり得な いのがこの触媒系の大きな特徽である。

3.2 .1 反応温度の影製：この触媒系では原料の一つとして水 を供給しているために水のゼオライト構造内での吸着平衡が問題 となり，アセトン生成速度は反応温度に大きく依存する。困了に ブロピレンの転化率および反応生成物の選択家におよぼす反応温 度の影響を示す。反応温度が低すぎると細孔内での本の吸着ある

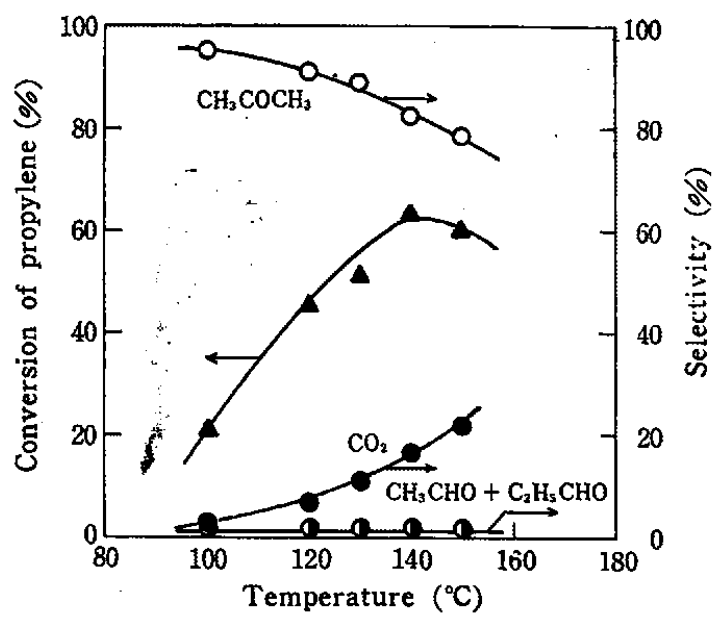

Fig. 3 Effect of reaction temperature on the propylene conversion and the product distribution

Propylene partial pressure 0.031 atm, Oxygen partial pressure $0.126 \mathrm{~atm}$, Water partial pressure $0.252 \mathrm{~atm}$, $W / F 9 \mathrm{~g}$-cat.hr/mol 
い性毛管凝樎が起こり，細孔内の活性サイトに存在する $\mathrm{Pd}($ II) イオンの有効利用の面からみて不利である。反応温度の上昇とと ると触媒活性す上昇するが， $140^{\circ} \mathrm{C}$ を最高にしてそれ以上ではむ しろ低下する。これは高い反応温度では Pd(II)へのブロピレン の配位が不暞になるためと考えられる。反応生成物の選択率は反 応温度の影遙を受け，温度が高くなるにつれてアセトンの選択率 は減少し，一方，二酸化炭素の選択率は上昇するが，副成するア セトアルデヒドとプロピオンアルデヒドは $1 \%$ 程度で大きな変 化はない。アセトンを取率よく得るためにす，またゼオライトに 配圆されているイオンの安定性, すなわちイオンの凝集や金属酸 化物の形成を防ぐ意味に蛙いてる $140^{\circ} \mathrm{C}$ 以上の高温で反応を行 ならことは好ましくない。

3.2.2 酸菜分圧の影翌 : この $\mathrm{Pd}(\mathrm{II})-\mathrm{Cu}(\mathrm{II})-\mathrm{Y}$ を使用した 触媒系の反诘を Riekert らの表現にならって示せばつぎの（1） （3）式で表わされるであろう。

$\left[\mathrm{Pd}^{2+} 2 \mathrm{Z}^{-}\right]+\mathrm{C}_{3} \mathrm{H}_{6}+\mathrm{H}_{2} \mathrm{O}$

$$
\longrightarrow \mathrm{CH}_{3} \mathrm{COCH}_{3}+\left[\mathrm{Pd}^{0}, 2\left(\mathrm{H}^{+} \mathrm{Z}^{-}\right)\right]
$$

$\left[\mathrm{Pd}^{0}, 2\left(\mathrm{H}^{+} \mathrm{Z}^{-}\right)\right]+2\left[\mathrm{Cu}^{2+} 2 \mathrm{Z}^{-}\right]$

$$
\longrightarrow\left[\mathrm{Pd}^{2+} 2 \mathrm{Z}^{-}\right]+2\left[\mathrm{Cu}^{+} \mathrm{Z}^{-}, \mathrm{H}^{+} \mathrm{Z}^{-}\right]
$$

$2\left[\mathrm{Cu}^{+} \mathrm{Z}^{-}, \mathrm{H}^{+} \mathrm{Z}^{-}\right]+1 / 2 \mathrm{O}_{2} \longrightarrow 2\left[\mathrm{Cu}^{2+} 2 \mathrm{Z}^{-}\right]+\mathrm{H}_{2} \mathrm{O}$

酸秦が直接関与するのは（3）式であるが，(3) 式の反応が他の

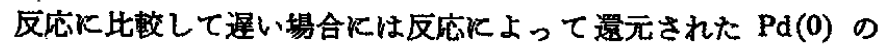
再酸化は十分飞進行せず，一部の $\operatorname{Pd}(0)$ はそのまま0価にとど まり，活性低下の現象がみられるであうう。事実，酸素分圧がブ ロピレン分仕よりる小の場合は活性低下が起こる。図4 Kは活性 低下を起こさない酸素分王範囲での実験結果を示す。酸素分压が $0.064 \mathrm{~atm}$ 以上では活性低下は癹められず, ブロピレンの転化率 あ約 52\% で一定である。この範囲では酸素分压は反応生成物分 布に大きな影響を与えない。酸素分圧が $0.25 \mathrm{~atm}$ では二酸化炭 素の選択率がわずか炕上昇し，アセトンの選択率が若干低下する 程度である。

3.2 .3 水蒸気分匤の影䡉 : プロピレン分圧と酸素分圧を一定 とし，接触時間を一定にたすつよう窒素で調節しながら，水蒸気 分圧を変化させてその影響を検討した。四 5 亿示すよらに，水蒸 気分刅がアセトン生成速度に大きな影響を与えていることが明ら かである。水蒸気分圧が大机なればプロピレンの転化率は上昇す

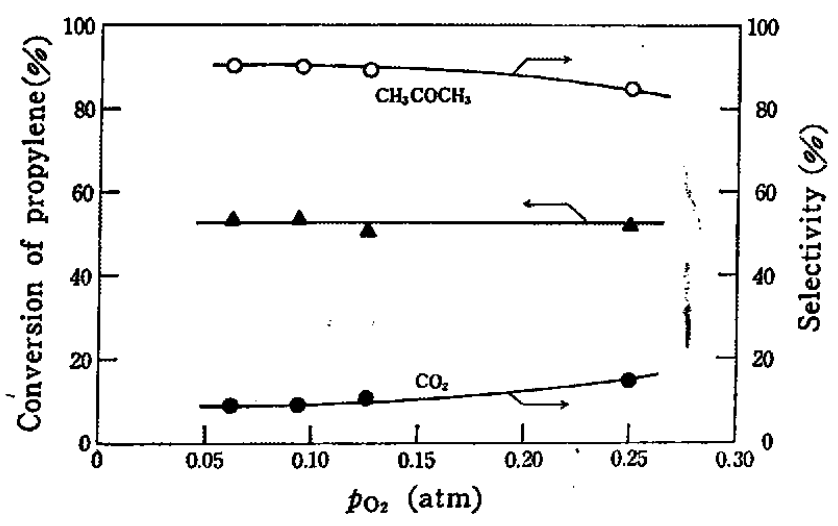

Fig. 4 Effect of oxygen partial pressure on the propylene conversion and the product distribution

Temperature $130^{\circ} \mathrm{C}$, Propylene partial pressure $0.032 \mathrm{~atm}$, Water partial pressure $0.251 \mathrm{~atm}, W / F 9.0 \mathrm{~g}-\mathrm{cat} \cdot \mathrm{hr} / \mathrm{mol}$

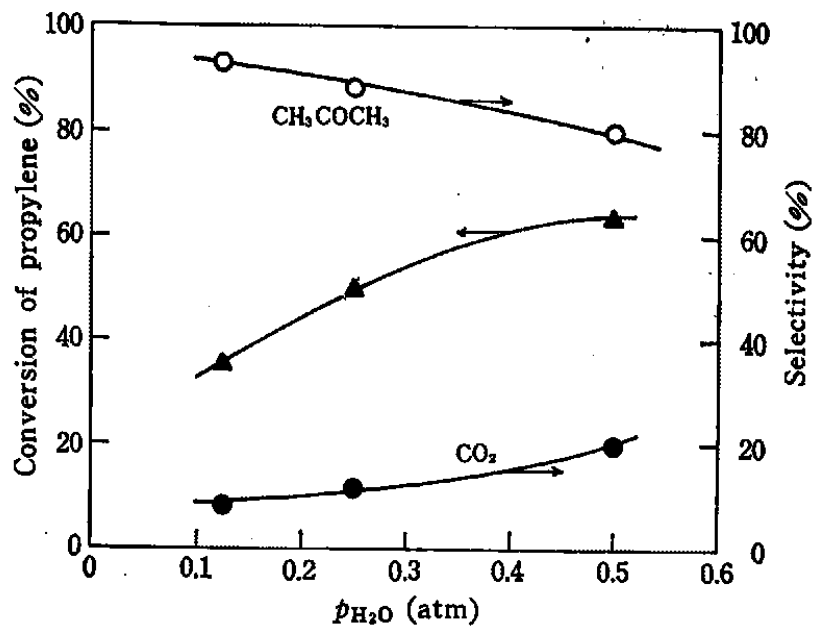

Fig. 5 Effect of water partial pressure on the propylene conversion and the product distribution

Temperature $130^{\circ} \mathrm{C}$, Propylene partial pressure $0.032 \mathrm{~atm}$, Oxygen portial pressure $0.125 \mathrm{~atm}, W / F 9 \mathrm{~g}$-cat $\cdot \mathrm{hr} / \mathrm{mol}$

るが，アセトンの選択率は減少し、二酸化炭秦の選択率は増加す る。な牧，二酸化炭素の生成は原料のプロピレンの直接的な燃炾 によるものか，または反応生成物である含酸素化合物の逐次的反 応火よるるのか恃明らがはない。

3.2.4 プロビレン分圧の影暗 : 酸素分圧と办蒸気分圧を固定 し，接触時間を一定にするよら窒秦でバランスをとりながらブロ ピレン分圧を変化させてその影留を検討した。その結果を图6 6 K 示す。プロピレン分圧を変化させてもアセトンおよび二酸化炭秦 の選択率はほとんと変化がなかった。プロピレン分仕は武(1)の アセトン生成速度に直接関与しており，選択率仅変化がないこと からプロピレン分圧を大にする方が合成論的炕は好ましいが，式 (2)，(3）飞拈ける Pd(0)の再酸化を考虑しなければならない。

3.2 .5 接触時間の影響: プロピレン，酸素および木蒸気の分 圧を一定にして接触時間の反応生成物に和よぼす影慜について検 討した結果を図 7 亿示す。主生成物のアセトンおよび副生する二 酸化炭素とも接触時間ととすに増加するが，それぞれの選択率性

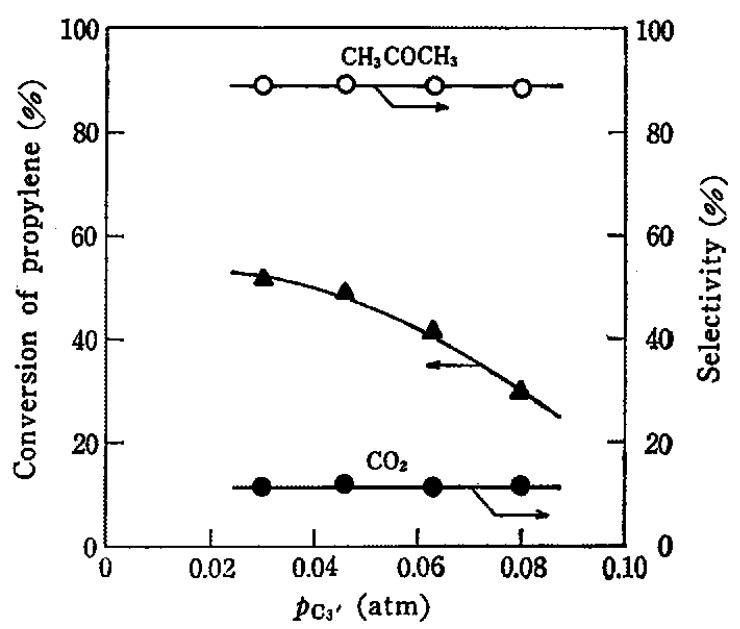

Fig. 6 Effect of propylene partial pressure on the propylene conversion and the product distribution

Temperature $130^{\circ} \mathrm{C}$, Oxygen partial pressure $0.125 \mathrm{~atm}$, Water partial pressure $0.251 \mathrm{~atm}, W / F 9 \mathrm{~g}$-cat $\cdot \mathrm{hr} / \mathrm{mol}$ 


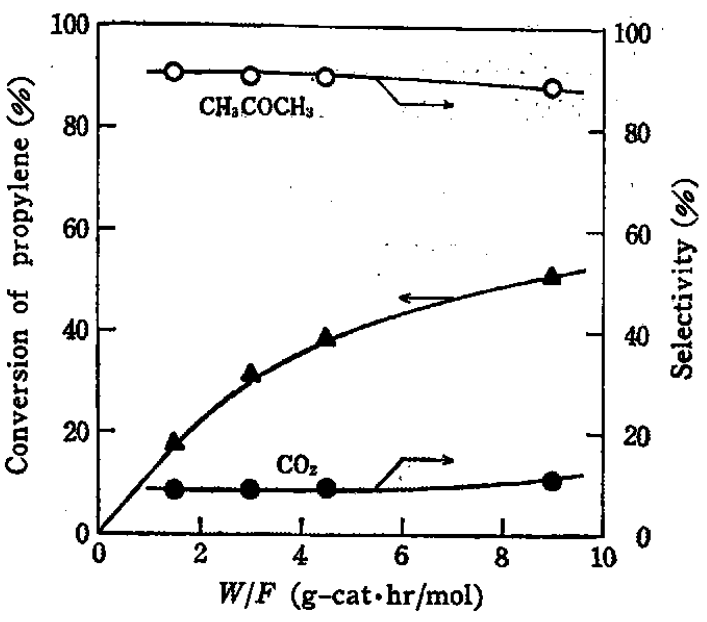

Fig. 7 Effect of $W / F$ on the propylene conversion and the product distribution

Temperature $130^{\circ} \mathrm{C}$, Propylene partial pressure $0.032 \mathrm{~atm}$, Oxygen partial pressure $0.125 \mathrm{~atm}$, Water partial pressure $0.251 \mathrm{~atm}$

ほとんと変化しない。またアセトアルデヒドおよびブロピオンד ルデヒドなどが副生するが選択率は 1 2\% で恬とんと変化がな い。二酸化炭素がこれらのアルデヒドを経由して生成するのか， またはブロビレンの直接酸化によるるのか，あるいはこれらの両 径路によるのか断定するに足りない。

以上反応諸条件のアセトン生成に対する影響について記述した が，目的生成物であるアセトンを収率よく得るためには酸素およ び本蒸気分压を大にし，接触時間を長くするとともに反応温度を 130 140 $\mathrm{C}$ に選ら゙のが好ましいことが知られる。Pd(II) および $\mathrm{Cu}$ (II) イオンの担持量を可変因子として含む 速度論的研究につ いては次報に譲ることにする。

\section{3 触媒活性におよばすアンモニアの影䁹}

この $\mathrm{Pd}(\mathrm{II})-\mathrm{Cu}(\mathrm{II})-\mathrm{Y}$ 触媒系に战ける触蝶活性種火ついて若 干の検討を加えた。触媒調製のためのイオン交換飞 $\mathrm{Pd}\left(\mathrm{NH}_{8}\right)_{4} \mathrm{Cl}_{2}$ 水溶液を使用していることから，触媒の最初の組成は $\mathrm{Pd}\left(\mathrm{NH}_{\mathrm{s}}\right)_{4}$ （II）-Cu（II）-Y の形で表わされると思われる。従来, 均一系代打 いて明らか比されている反機構22)飞基ついて考えれば，Pd(II) に最初に配位している 4 個のアンミン配位子のらち，少なくとす I個の水分子と 1 個のブロピレン分子が配位するためには 2 個の アンミン配位子が脱離する必要がある。反応生成物中にはアンモ ニアは認められないから，アンモニアは能媒のなんらかのサイト 吙着されているすのと考えられる。

そこで供給する水に少量のアンモニアを添加した。図8にみる ようにアンモニア供給速度が大であるほどはや活性低下が起こ ることが知られた。そして，アンモニア供給速度が $2.55 \times 10^{-4}$ $\mathrm{mol} / \mathrm{g}$-cat·hr の場合には 6 时間目まで反応ガス中にアンモニア

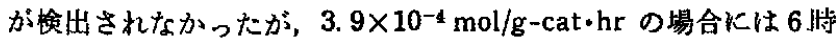
間目からアンモニアが検出され，両者とも反応後の触媒は $\mathrm{Cu}($ III $)$ アンミン錯イオンの色調を示した。これらは, アンモニアの共存 によって水扰よびプロピレン分子の $\mathrm{Pd}(\mathrm{II})$ への配位が妨げられ るすのと考えられる。また，Cu(II) へのアンモニアの配位によ b) $\operatorname{Pd}(0)$ の再酸化速度が低下寸る可能性もある。

22) P. M. Henry, J. Amer. Chem. Soc., 86, 3246(1964).

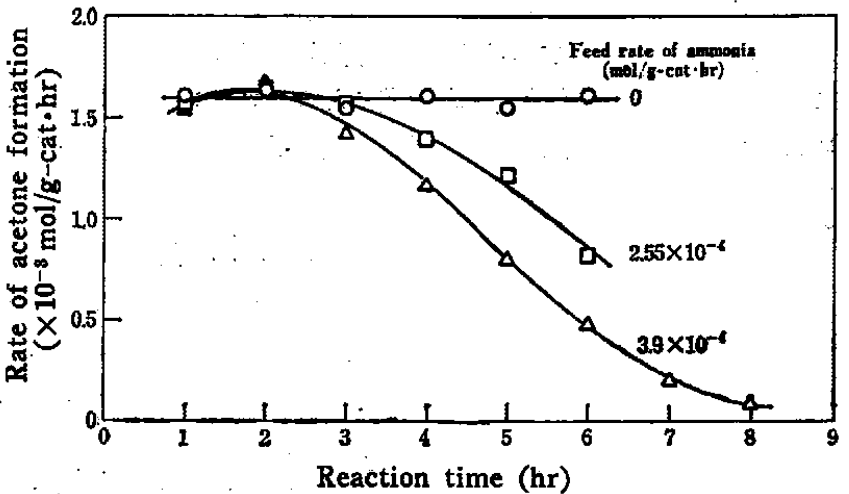

Fig. 8 Effect of ammonia on the acetone formation Temperature $130^{\circ} \mathrm{C}$, Propylene partial pressure $0.031 \mathrm{~atm}$, Oxygen partial pressure $0.125 \mathrm{~atm}$, Water partial pressure $0.252 \mathrm{~atm}, W / F 9 \mathrm{~g}$-cat $\cdot \mathrm{hr} / \mathrm{mol}$

つぎ飞二段目のイオン交換を $\mathrm{Cu}\left(\mathrm{NH}_{8}\right)_{6}$ (II) 水溶液火よって行 なって得た $\mathrm{Pd}\left(\mathrm{NH}_{9}\right)_{4}$ (II)-Cu( $\left(\mathrm{NH}_{3}\right)_{8}$ (II)-Y 触媒を用いた実験結 果を図 9 と示す。反応初期飞ははとんど触媒活性を示さないか， 反応時間とともに活性が上界し 5 時間後は一定の活性を示す上5 になった。Pd(II)-Cu(II)－Y触媒化比較して触媒活经はいちじる しく低いか， Pd(II) の担持量が $9.5 \times 10^{-5} \mathrm{~atm} / \mathrm{g}$-cat であるか ら触媒としての䤶きは十分飞認められる。この埸合少量のアンモ ニアの流出が認められ， $\mathrm{Pd}\left(\mathrm{NH}_{8}\right)_{4}$ (II) イオンのアンミン配位子 が脱離し，プロピレンホよび本分子が配位可能な状態になると考 えられる。反応 8 時間ののら，プロピレンの供給を停止し，触媒

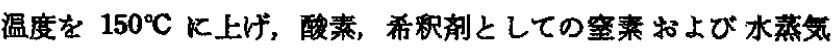
を供給しながら 2 時間処理した。ここで温度を $130^{\circ} \mathrm{C}$ にもどし てブロビレンの供給を開始したところ，触媒活性恃初期にくらべ て約 5 倍程度上昇した。この現象は $\mathrm{Pd}(\mathrm{II})$ および $\mathrm{Cu}$ (II) イオ ンに配位していたアンモニアが脱離して少なくも部分的にアコ化 され，アセトン生成および（あるいは） $\operatorname{Pd}(0)$ の再酸化速度がは やめられたためと考えれば矛盾はない。

以上の結果から，活性種は $\mathrm{Pd}\left(\mathrm{NH}_{8}\right)_{4}$ (II) から少なくす2個 以上のアンモニア分子が水分子に置換されて生じた $\mathrm{Pd}\left(\mathrm{NH}_{3}\right)_{x}$. $\left(\mathrm{H}_{2} \mathrm{O}\right)_{4-x}$ (II) $(0 \leqq x \leqq 2)$ であることが推測される。また $\mathrm{Cu}(\mathrm{II})$

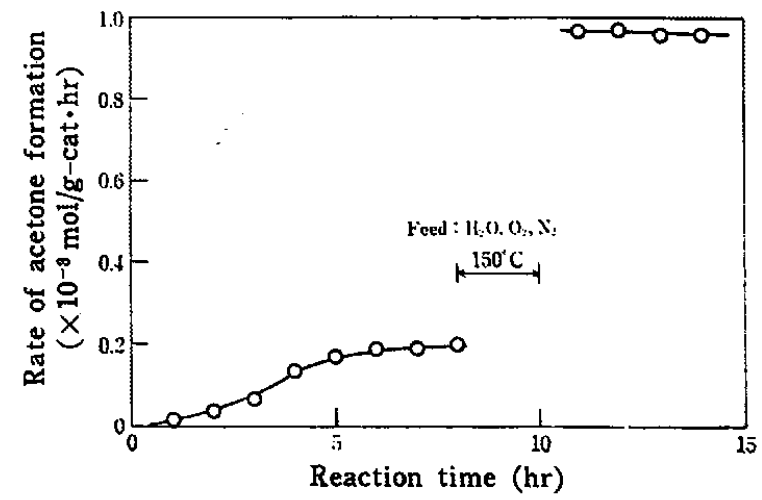

Fig. 9 Oxidation of propylene over $\mathrm{Pd}\left(\mathrm{NH}_{3}\right)_{4}$ (II)-Cu. $\left(\mathrm{NH}_{3}\right)_{6}$ (II)-Y Zeolite catalyst

Temperature $130^{\circ} \mathrm{C}$, Propylene partial pressure $0.031 \mathrm{~atm}$, Oxygen partial pressure $0.126 \mathrm{~atm}$, Water partial pressure $0.252 \mathrm{~atm}, W / F 9 \mathrm{~g}$-cat $\cdot \mathrm{hr} / \mathrm{mol}$ 
イオンす $\mathrm{Cu}\left(\mathrm{NH}_{8}\right)_{8}$ (III) イオンでは $\mathrm{Pd}(0)$ 孝十分な速度で再酸 化することができず、フイオンの状態が望ましいと考えられる。 このよ5K Pd(II)-Cu(II)-Y 触媒仗よずロピレンの酸化反沁

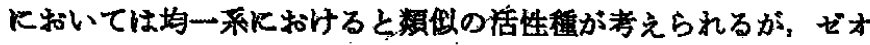

ライト格子内の定められたサイトに位置する $\mathrm{Pd}(0)$ と $\mathrm{Cu}(\mathrm{II})$ の䦓の電子移行がとのよらな機作によって行なわれるかは今後明 らかにされなければならない課題であろら。

\title{
Oxidation of Propylene over $\mathrm{Pd}(\mathrm{II}) \cdot \mathrm{Cu}(\mathrm{II})-\mathrm{Y}$ Zeolite Catalyst in the Presence of Steam
}

\author{
Toshihiko Kubo, Fumio Kumada, Hiroo Tominaga \\ and Taiseki Kunugr \\ Department of Synthetic Chemistry, Faculty of Engineering, \\ University of Tokyo; Hongo, Bunkyo-ku, Tokyo, Japan
}

The $\mathrm{Pd}(\mathrm{II})-\mathrm{Cu}(\mathrm{II})-\mathrm{Y}$ zeolite catalyst was prepared by two-step ion exchange of $\mathrm{Na}^{+}$; in the first place with $\mathrm{Pd}\left(\mathrm{NH}_{3}\right)_{4} \mathrm{Cl}_{2}$ aqueous solution, and in the second with $\mathrm{CuCl}_{2}$ aqueous solution. Vapor phase oxidation of propylene in the presence of steam over the catalyst in the temperature range of $100 \sim 150^{\circ} \mathrm{C}$ at atmospheric pressure gives acetone with good yield comparable to the homogeneous catalytic systems. Selectivity of acetone formation was higher than $80 \%$. By-products were carbon dioxide, acetaldehyde, propionaldehyde and trace amount of acids. These results suggested that electron transfer occurred from $\mathrm{Pd}(0)$ to $\mathrm{Cu}(\mathrm{II})$ existing in the definite sites of the zeolite structure. The catalyst deactivation by ammonia addition and the low catalytic activity of the $\mathrm{Pd}\left(\mathrm{NH}_{3}\right)_{4}$ (II)-Cu(NH$)_{3}(\mathrm{II})-\mathrm{Y}$ zeolite catalyst suggested that the active species were the partially aquated $\mathrm{Pd}(\mathrm{II})$, and $\mathrm{Cu}(\mathrm{II})$ ions.

\section{ポリ (2-ヒドロキシアルキル=アクリラート) とケイ皮酸クロリドの 反応による感光性樹脂の合成 ${ }^{122}$}

(1972 年 2 月 10 日受理)

西久保忠臣・綿 内輝夫 夫牧 喜代志・高岡 恒 郎*

\begin{abstract}
ヘキサメチルホスホルフミド (HMPA) 中で，2-ヒドロキシェチルニフクリラートおよび 2-ヒドロキシブロピルニア クリラートを重合し，2-とドロキシェヂルンフリラートと酢酸ビニルを共重合した。得られたそれぞれの゚リマー 溶液にケイ皮酸クロリド加え縮合反応を行ない，睢鎖にケイ皮酸エステル基を有する光檑かけ性ポリマーを合成し た。この方法で得られたポリマーはトルェン, MEKなどの有機溶媒に可溶であった。得られたポリマーに, 增感剂 として 5-ニトロアセナフテンを加えて相対感度を測定した結果，KPR（ポリケイ皮酸ビ二ル型感光性樹脂）飞比較

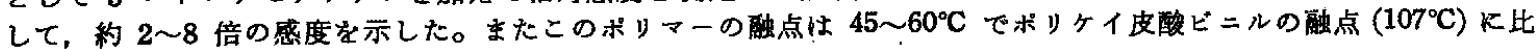
较して低かった。
\end{abstract}

\section{1 緒䇾}

ポリケイ皮酸ビニルが Minsk ら ${ }^{8) 4}$ により.報告されて以来， 種々の感光性樹脂の合成が報告され，高感度の感光性樹脂の合成 が娭討されてきた。ポリ多イ皮酸ビニルは熱安定性がよいために

1）この報文を “感光性樹脂に関する研究(第 2 報)”，とする。

2）前報(第 1 報)，西久保忠臣，富山嘉子，牧喜代志，高岡 恒郎, 高分子化学, 29, 295(1972).

* 日本オイルシール工業株式会社化学研究部, 神奈川県藤㳄 市社堂新町

3) L. M. Minsk, J. G. Smith, W. P. Van Deusen, J. F. Wright, J. Appl. Polym. Sci., 2, 302(1959).
有用な感光性樹脂であるが，融点が高いためにその使用が制限さ れる場合もある。ケイ皮酸ビニル以外のケイ皮酸エステル型の感 光性樹脂の合成が報告されているが，軟化点が低いと思われるボ リマーは，わずかにエチレンーケイ皮酸ビニル共重合体 ${ }^{6)}$ ，酿酸ど ニルケイ皮酸ビニル共重合体"，ポリビニロキシエチルケイ皮酸 エステル7が報告されているにすぎない。また $\beta$ ーヒドロキシア

4) E. M. Robertson, W.P. Van Deusen, L. M. Minsk, J. Appl. Polym. Sci., 2, 308(1959).

5) L. M. Minsk et al., U. S. P., 2, 801, 233(1957).

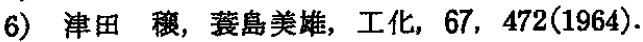

7) M. Kato, T. Ichijo, M. Hasegawa, J. Polym. Sci., B 8, 263(1970). 